\title{
The Tubulin Code in Mitosis and Cancer
}

\author{
Danilo Lopes ${ }^{1,2}$ and Helder Maiato $1,2,3, *$ (D) \\ 1 Chromosome Instability \& Dynamics Group, i3S-Instituto de Investigação e Inovação em Saúde, \\ Universidade do Porto, Rua Alfredo Allen 208, 4200-135 Porto, Portugal; danilo.lopes@i3s.up.pt \\ 2 Instituto de Biologia Molecular e Celular, Universidade do Porto, Rua Alfredo Allen 208, \\ 4200-135 Porto, Portugal \\ 3 Cell Division Group, Experimental Biology Unit, Department of Biomedicine, Faculdade de Medicina, \\ Universidade do Porto, Alameda Prof. Hernâni Monteiro, 4200-319 Porto, Portugal \\ * Correspondence: maiato@i3s.up.pt; Tel.: +351-22-040-8800
}

Received: 28 September 2020; Accepted: 24 October 2020; Published: 26 October 2020

check for updates

\begin{abstract}
The "tubulin code" combines different $\alpha / \beta$-tubulin isotypes with several post-translational modifications (PTMs) to generate microtubule diversity in cells. During cell division, specific microtubule populations in the mitotic spindle are differentially modified, but only recently, the functional significance of the tubulin code, with particular emphasis on the role specified by tubulin PTMs, started to be elucidated. This is the case of $\alpha$-tubulin detyrosination, which was shown to guide chromosomes during congression to the metaphase plate and allow the discrimination of mitotic errors, whose correction is required to prevent chromosomal instability-a hallmark of human cancers implicated in tumor evolution and metastasis. Although alterations in the expression of certain tubulin isotypes and associated PTMs have been reported in human cancers, it remains unclear whether and how the tubulin code has any functional implications for cancer cell properties. Here, we review the role of the tubulin code in chromosome segregation during mitosis and how it impacts cancer cell properties. In this context, we discuss the existence of an emerging "cancer tubulin code" and the respective implications for diagnostic, prognostic and therapeutic purposes.
\end{abstract}

Keywords: cancer; chromosomal instability; microtubule; mitosis; tubulin code; tubulin post-translational modifications

\section{The Tubulin Code}

Microtubules are dynamic, hollow cylindrical structures typically formed by thirteen laterally associated protofilaments of $\alpha / \beta$-tubulin heterodimers that interact head-to-tail [1]. $\alpha$ - and $\beta$-tubulin proteins are encoded by several different genes (also known as tubulin isotypes) that diverge in their C-terminal tail regarding length and amino acid composition [2,3]. In eukaryotes, the expression and distribution of different tubulin isotypes is cell- and tissue-specific [2]. In addition, $\alpha$ - and $\beta$-tubulin isotypes may undergo multiple post-translational modifications (PTMs). As $\alpha / \beta$-tubulin heterodimers polymerize into microtubules, the combination of isotype expression with PTMs generate microtubule diversity or a "tubulin code" (Figure 1), which has been implicated in the regulation of microtubule properties and functions underlying fundamental cellular processes $[4,5]$.

Acetylation, detyrosination, polyglutamylation and polyglycylation are amongst the best characterized tubulin PTMs (Figure 1). Acetylation occurs in both $\alpha$ - and $\beta$-tubulins, more specifically at the luminal-side Lysine-40 (K40) of $\alpha$-tubulin [6,7] and Lysine 252 (K252) of $\beta$-tubulin [8]. While K252 is modified by the acetyltransferase San [8], K40 is acetylated by the acetyltransferase MEC-17/ $\alpha$ TAT1 $[9,10]$ and deacetylated by histone deacetylase 6 (HDAC6) and sirtuin2 (SIRT2) [11,12]. When incorporated into microtubules, $\alpha$-tubulin can also be detyrosinated, which consists on the catalytic removal of the last tyrosine present at the C-terminal tail of most isoforms 
by tubulin carboxypeptidases (TCPs), including the recently identified Vasohibin 1 (VASH1) and Vasohibin 2 (VASH2) complexes with their associated Small Vasohibin-Binding Protein (SVBP) [13-19]. As microtubules depolymerize, soluble detyrosinated $\alpha$-tubulin can be retyrosinated by a highly specific tubulin tyrosine ligase (TTL) that closes the cycle $[20,21]$. Noteworthy, additional TCPs remain to be identified, as substantial $\alpha$-tubulin detyrosination still occurs in human cells in which both Vasohibin-encoding genes were knocked out by CRISPR-Cas9 [14]. After detyrosination, $\alpha$-tubulin C-terminal tails may also be subject to the removal of the penultimate and antepenultimate glutamates by cytosolic carboxypeptidases (CCPs) [22,23], leading to formation of the non-tyrosinatable $\Delta 2$ - and $\Delta 3$-tubulin, respectively [24,25]. Additionally, C-terminal tails of both $\alpha$ - and $\beta$-tubulins undergo side-chain polyglutamylation and polyglycylation $[26,27]$. The single or consecutive addition of glutamate residues to the $\gamma$-carboxyl group of C-terminal tails is performed by several TTL-like (TTLL) (poly)glutamylases $[5,28,29]$ and is/are removed by a set of CCPs known as deglutamylases $[5,22,23,30]$. Similarly, the addition of glycine residues relies on the (poly)glycylases TTLL3, TTLL8 and TTLL10 [31,32], but the identity of tubulin deglycylases remains unknown. Lastly, several other tubulin PTMs, such as methylation, polyamination, phosphorylation, ubiquitinylation, sumoylation, palmitoylation (reviewed in [5]) and O-GlcNAcylation [33] occur in the tubulin core structure adjacent to the C-terminal tails. These PTMs remain poorly characterized at the functional level but are likely to be implicated in microtubule assembly and dynamics $[5,34,35]$.

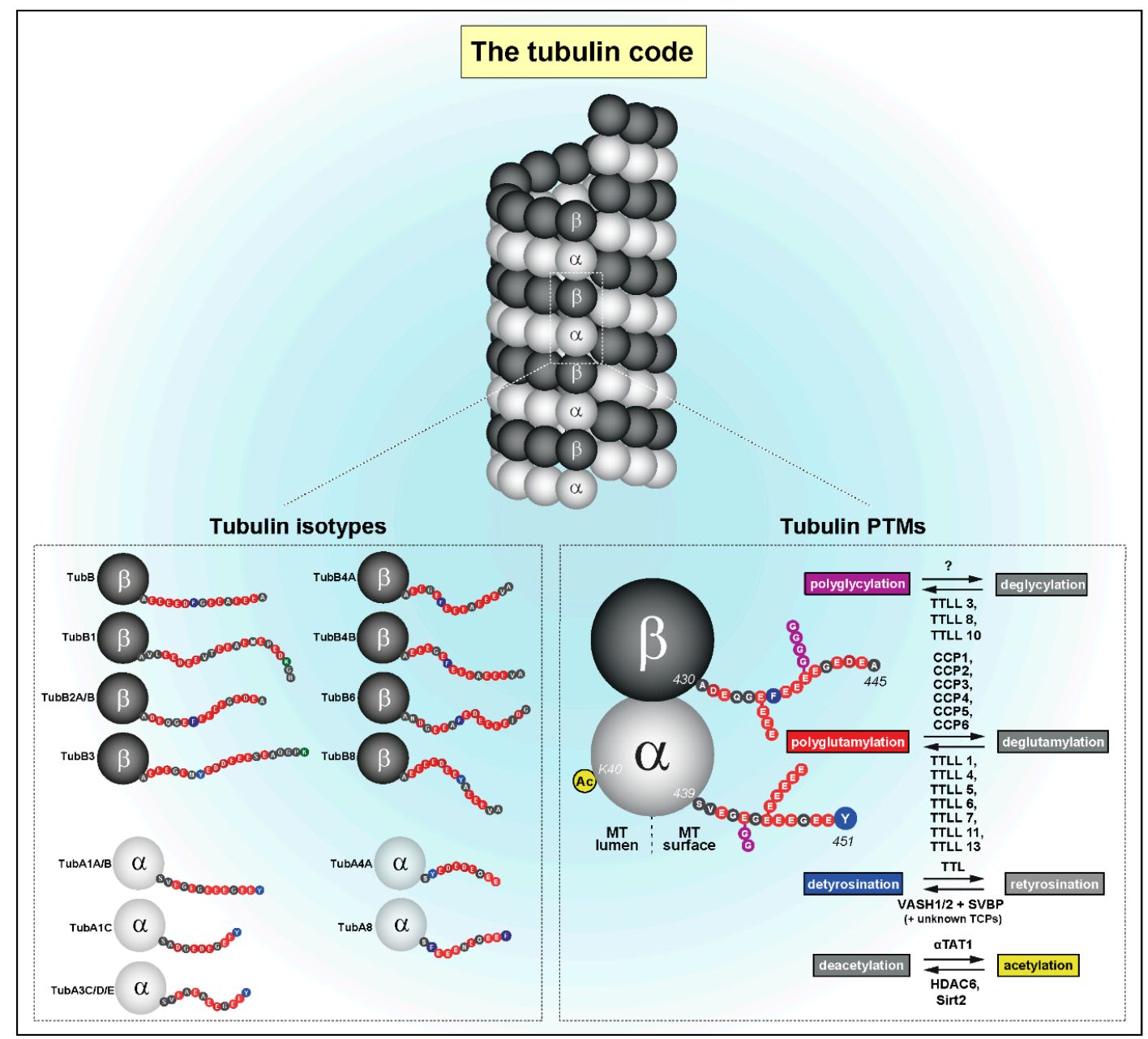

Figure 1. The tubulin code combines different tubulin isotypes and post-translational modifications (PTMs) to generate microtubule diversity. Only the best-characterized isotypes and PTMs (+ respective enzymes) are depicted. See main text for details. 


\section{The Tubulin Code in Mitosis}

Mitosis relies on the critical contribution of microtubules, as well as several microtubule-associated proteins (MAPs) and motors, to regulate several key mechanisms underlying the faithful segregation of the genetic material during cell division. It involves the assembly of a specialized microtubule-based structure known as the mitotic spindle. Due to their intrinsic dynamic nature, mitotic spindle microtubules are vastly tyrosinated, i.e., remain essentially nonmodified (note that most gene-encoded $\alpha$-tubulin isoforms carry a last Tyrosine residue at their C-terminal tails; see Figure 1). As some spindle microtubules become gradually stabilized due to the establishment of chromosome attachments at the kinetochore, as well as possible interactions between some interpolar microtubules, they become increasingly detyrosinated [19,36-40] (Figure 2). Likewise, kinetochore microtubules are highly acetylated on the K40 of $\alpha$-tubulin [36,41] and polyglutamylated [42] and accumulated $\Delta 2$-tubulin [43]. The actions of spindle microtubules during mitosis is regulated by several MAPs [44] and assisted by several motor proteins [45]. For instance, the initial capture and transport of peripheral chromosomes by microtubules is mediated by dynein/dynactin [46-49], a minus-end-directed motor localized at unattached kinetochores [50,51], whereas the subsequent congression to the spindle equator is mediated by another kinetochore-associated motor, Centromere Protein E (CENP-E)/kinesin-7, with microtubule plus-end-directed activity [52,53]. Other mitotic motors include kinesin-5, which slides antiparallel microtubules to ensure proper centrosome separation, spindle bipolarity and spindle elongation during anaphase, as well as kinesin-13s, which lack motor activity but promote microtubule depolymerization to control spindle length and mediate mitotic error correction [54-59]. Thus, the mitotic spindle is an anisotropic and highly heterogeneous structure, with dynamic astral microtubules essentially tyrosinated, in contrast with more stable microtubule subpopulations, such as kinetochore and a fraction of interpolar microtubules, which accumulate detyrosinated, $\Delta 2$, acetylated and polyglutamylated tubulin. How these modifications impact the action of the different mitotic motors that assist chromosome segregation remains poorly understood.

\subsection{A Navigation System Guides Chromosomes to the Spindle Equator}

Although tubulin diversity in the mitotic spindle has been recognized for several decades, the respective functional relevance for mitosis remained unclear until recently. One crucial implication of the tubulin code hypothesis is the regulation of MAPs and motors by specific tubulin isotypes and PTMs [4]. Original work in neurons revealed that classic kinesin motors, such as Kinesin-1, are able to recognize and have a preference for microtubules with particular tubulin PTMs, namely detyrosination and acetylation $[60,61]$. Subsequently, $\alpha$-tubulin detyrosination was shown to regulate mitotic chromosome congression to the metaphase plate by guiding the microtubule plus-end-directed motor CENP-E/kinesin-7 at kinetochores in human cells [36]. In contrast, the microtubule minus-end-directed motor dynein/dynactin that is also localized at unattached kinetochores $[50,51]$ preferentially associates with tyrosinated microtubules [40,62-64], which favor the initiation of motion but are dispensable for subsequent dynein/dynactin processivity $[63,64]$. Thus, detyrosinated/tyrosinated $\alpha$-tubulin regulates the activity of opposing kinetochore motors, establishing a navigation system for chromosomes that assists their congression to the spindle equator [65] (Figure 2). Accordingly, during the initial capture of chromosomes, dynein/dynactin counteracts the action of chromokinesins on chromosome arms to move peripheral chromosomes along tyrosinated astral microtubules towards the vicinity of the poles [66]. By transporting peripheral chromosomes to the poles where the microtubule destabilizing activity of Aurora A kinase is higher [67,68], dynein/dynactin prevents the formation of stable end-on kinetochore-microtubule attachments that would otherwise cause the random ejection of polar chromosomes by chromokinesins $[65,66]$. Once at the poles, Aurora A-mediated phosphorylation activates CENP-E at kinetochores of polar chromosomes [69], thus allowing their transport specifically along detyrosinated spindle microtubules towards the equator. In agreement, recent super-resolution coherent-hybrid stimulated emission depletion microscopy [70] of CENP-E-GFP revealed its exclusive association with stable kinetochore and interpolar microtubule bundles but 
not with tyrosinated astral microtubules [71]. Curiously, $\alpha$-tubulin acetylation on K40, which is also enriched on stable spindle microtubules [41], does not interfere with polar chromosome congression [36]. While the potential contribution of other tubulin PTMs to chromosome congression remains unknown, these findings support a robust working model in which tyrosinated/detyrosinated microtubules guide peripheral chromosomes towards the spindle equator.

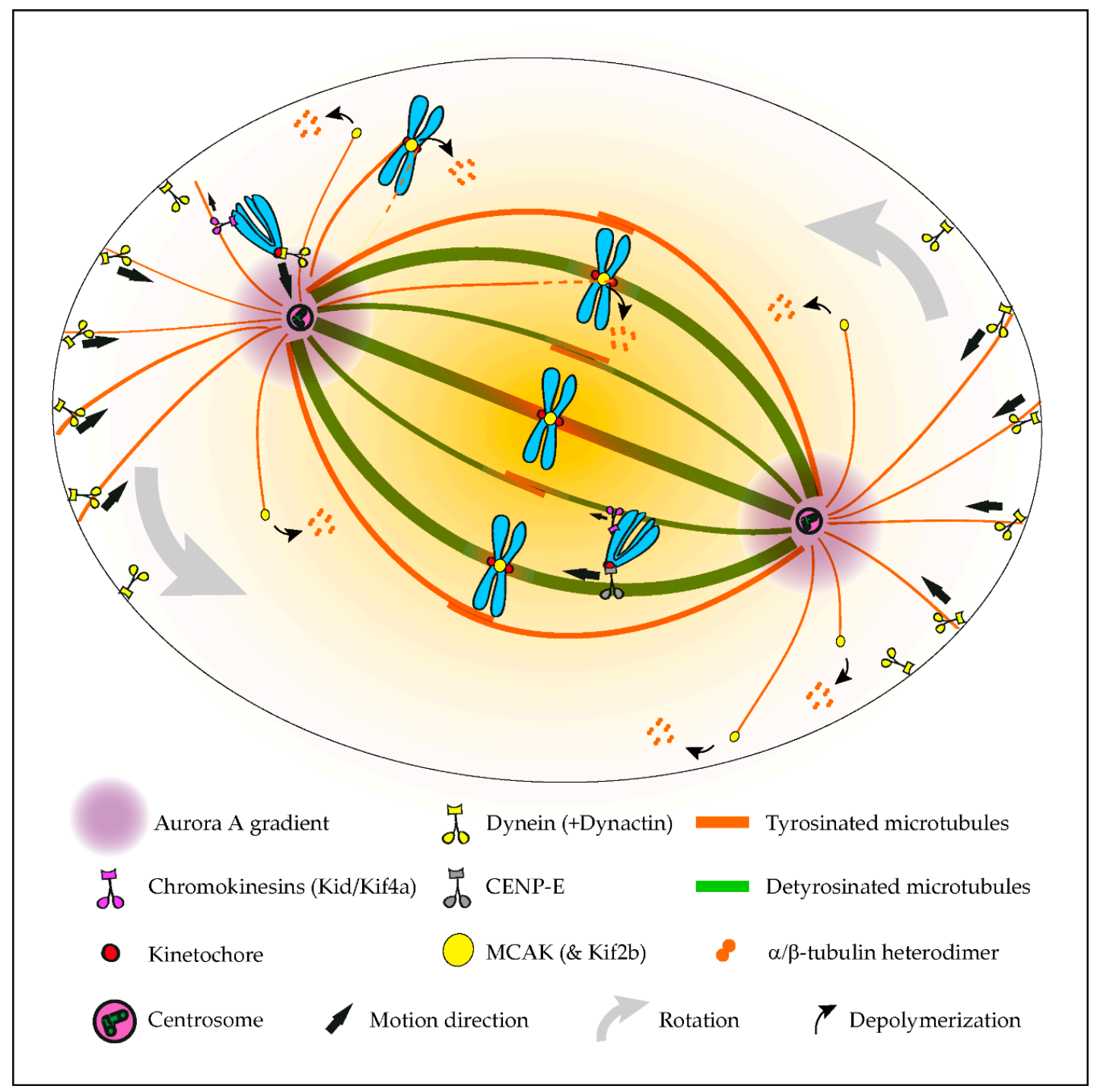

Figure 2. Summary of the established roles of the tubulin code in mitosis. The initial capture of peripheral chromosomes is mediated by dynein/dynactin at kinetochores, upon which, the chromosome is brought to the vicinity of the centrosome by lateral transport along tyrosinated astral microtubules. This prevents the random ejection of the chromosome by the action of Chromokinesins on chromosome arms. Once at the pole, high Aurora A activity prevents the stabilization of end-on kinetochore-microtubule attachments, which otherwise would favor the action of Chromokinesins on chromosome arms. In parallel, Aurora A-mediated phosphorylation activates CENP-E at kinetochores. This initiates transport towards the spindle equator (congression) along stable detyrosinated microtubules. Mitotic centromere-associated kinesin (MCAK) and Kif2b (not depicted) at centromeres and kinetochores are also inhibited by tubulin detyrosination on kinetochore microtubules, allowing the correction of syntelic and merotelic attachments, while preserving correct amphitelic attachments on bi-oriented chromosomes. MCAK at the microtubule plus ends also regulates astral microtubule length to allow interaction with dynein/dynactin at the cortex or cytoplasmic organelles (not depicted), which exerts pulling forces necessary for spindle orientation and positioning. See main text for details. 


\subsection{A Mitotic Error Code}

The regulation of kinetochore microtubule dynamics is essential for error correction and the maintenance of genome stability, since it allows the establishment of amphitelic kinetochore-MT attachments that lead to chromosome biorientation relative to the spindle poles. Kinesin-13s, such as Kinesin superfamily $2 b$ (Kif2b) and mitotic centromere-associated kinesin (MCAK), promote kinetochore microtubule dynamics, thus playing a key role in the correction of mal-oriented chromosomes with erroneous kinetochore-microtubule attachments (e.g., syntelic, in which both sister kinetochores are oriented towards a single spindle pole, and merotelic, where a single kinetochore is attached with microtubules oriented to both poles) and, ultimately, in the prevention of chromosome mis-segregation [55,72] (Figure 2). In agreement, stimulation of kinetochore microtubule dynamics in otherwise chromosomally unstable cancer cells by increasing kinesin-13 depolymerase activity reestablished chromosomal stability $[55,73]$. Building on the previous finding that MCAK's microtubule depolymerizing activity is reduced four-fold in the presence of detyrosinated microtubules in vitro [74,75], it was recently shown that the mitotic error correction activity of MCAK and Kif2b is regulated by $\alpha$-tubulin detyrosination [37]. Accordingly, the experimental depletion of TTL or overexpression of VASH1-SVBP, which caused a constitutive increase of $\alpha$-tubulin detyrosination in the vicinity of the kinetochores, compromised error correction, leading to chromosome segregation errors. Importantly, $\alpha$-tubulin detyrosination specifically impaired the MCAK-based error correction machinery located on centromeres/kinetochores, and it did so without affecting global kinetochore microtubule dynamics, suggesting that mitotic error correction is exquisitely sensitive to the detyrosinated state of $\alpha$-tubulin that likely occurs at the individual microtubule level. These data support the existence of a "mitotic error code" in which $\alpha$-tubulin detyrosination/tyrosination signals and regulates MCAK activity at centromeres/kinetochores to discriminate between correct and incorrect kinetochore-MT attachments during mitosis (Figure 2).

Complete centrosome separation before nuclear envelope breakdown prevents subsequent segregation errors and ensures mitotic fidelity [76]. This relies on several elements, including the microtubule motors kinesin-5, required for centrosome separation, and dynein/dynactin, which promote both centrosome separation and positioning $[77,78]$. Similar to dynein/dynactin, kinesin-5 appears to have increased affinity to tyrosinated dendritic microtubules in neurons [79], but direct evidence from in vitro reconstitution assays is still lacking. Nonetheless, recent work in which centrosome positioning in human mitotic cells was tracked in 3D indicated that centrosome separation at nuclear envelope breakdown is insensitive to the tyrosinated state of $\alpha$-tubulin [37]. This reinforces the idea that the observed increase in mitotic errors associated with excessive $\alpha$-tubulin detyrosination is due to the incapacity to correct, rather than an increased propensity to make errors.

\subsection{Role in Mitotic Spindle Orientation and Positioning}

Mitotic spindle orientation and positioning in the cell center is essential for accurate cell division and relies on the action of pulling forces on astral microtubules [80]. In particular, dynein/dynactin anchored to cortical proteins or cytoplasmic organelles was shown to play a significant role in spindle orientation/positioning [81-83], possibly through its increased affinity to tyrosinated astral microtubules (Figure 1). Indeed, modulation of the $\alpha$-tubulin tyrosination state, either through TTL knockout [40] or CRISPR/Cas9-mediated editing of the C-terminal tyrosine [83], caused spindle orientation defects. In contrast, an experimental decrease of $\alpha$-tubulin detyrosination after VASH1/2 silencing increased the depolymerase activity of MCAK, resulting in disoriented spindles, with shorter astral microtubules [19]. Taken together, these observations indicate that the mechanisms behind spindle orientation/positioning rely on the intrinsic nature (i.e., nonmodified) of tyrosinated $\alpha$-tubulin to allow astral microtubules to establish a correct cell division plane (Figure 2). 


\subsection{Roles in Centrosome Structure and Cytokinesis}

Tubulin polyglutamylation is highly enriched on centriole microtubules $[42,84]$ and has been proposed to contribute to normal mitosis by maintaining centrosome structure $[84,85]$. Indeed, recent super-resolution imaging of the centriole structure revealed the specific distribution of polyglutamylation on centriole MTs and suggested a key role for this PTM in ultrastructural organization of specific centriolar proteins [86]. Furthermore, tubulin polyglutamylation promotes the activity of the microtubule-severing enzymes spastin and katanin [87-90], which are also implicated in cell division. Indeed, their activities regulate several cellular processes that likely impact chromosome segregation fidelity, such as microtubule poleward flux, spindle orientation and length [91-93]. Spastin and katanin are also required for the abscission step and completion of cytokinesis [94-96]. Like spastin [94] and katanin [96], polyglutamylated tubulin is enriched at the midbody [87], and a tubulin mutation that compromises polyglutamylation (and, possibly, also polyglycylation) in cilia was shown to cause cytokinesis defects [97]. These results suggest that the completion of cytokinesis relies on the regulation of spastin and katanin activities by tubulin polyglutamylation.

\section{The Cancer Tubulin Code}

\section{1. (De)Regulation of Tubulin Isotypes and PTMs in Cancer}

Several works have reported an emerging link between alterations of tubulin isotypes and PTMs and/or associated modifying enzymes with certain cancers; most noticeable, those occurring in the breast, colon, prostate, liver, brain, bile duct and pancreas (Table 1). These alterations often correlate with specific cancer properties, including poor outcome/prognosis [98-100] and metastatic ability [98], supporting the potential use of cancer tubulin isotypes and/or PTM signatures as useful biomarkers, as well as for therapeutic purposes. However, a comprehensive and definitive view on the real potential is still lacking, especially concerning causality, since the available data is still limited and often contradictory.

\subsection{Functional Implications of the Cancer Tubulin Code}

The differential regulation of specific tubulin isotypes and/or PTMs in cancer might reflect their role in key mechanisms underlying cell transformation (Figure 3). $\beta 3$-tubulin (TUBB3) is the most frequent tubulin isotype associated with specific cancer features. Its expression was proposed to be important for tumor development [101,102] and metastatic ability [102,103], correlating with poor outcomes $[103,104]$. The expression of other isotypes such as $\beta 2$-tubulin, and its altered cellular localization in colorectal cancer, also correlate with poor outcomes [105]. The differential expression of tubulin isotypes have been extensively associated with response to microtubule-targeting drugs, such as taxanes, commonly used in chemotherapy (reviewed in [106]). The origin of this link may be on the known regulation of microtubule dynamics by specific tubulin isotypes, with microtubules containing $\beta 3$-tubulin being more dynamic compared to other $\beta$-tubulin isotypes [107-109].

In addition, the regulation of cell proliferation, which is essential for cancer development, was proposed to be mediated by certain tubulin PTMs. In this regard, the tubulin glycylase TTLL3 was proposed to restrict cell proliferation in the colon and is downregulated in colon cancer [110], whereas the tubulin glutamylase TTLL4 was suggested to promote cell proliferation in pancreatic cancer cells [111]. However, whether this was specifically due to a role of TTLL4 in tubulin glutamylation remains controversial, since an additional activity towards non-tubulin substrates has been reported [112,113]. The tubulin acetyltransferase $\alpha$ Tat1 was also shown to be required for contact inhibition of cell proliferation in vitro [114]. In agreement, the tubulin deacetylase HDAC6 seems to promote cell proliferation in several cancer cell lines [115-119], consistent with its upregulation in some cancers (Table 1). Nevertheless, specificity remains to be demonstrated, since HDAC6 is also known to modulate the acetylation of other substrates besides tubulin [120]. Interestingly, the activity of TTLL3 and HDAC6 was also proposed to impact tumorigenesis. Accordingly, the experimental loss 
of TTLL3 in a mouse model of tumorigenesis resulted in the development of cancer, thus validating its downregulation in colon cancer and suggesting a cancer-suppressing role for tubulin glycylation [110]. In contrast, the expression of HDAC6 promoted colony and spheroid formation of cancer cells, as well as tumor growth in mice $[115,116,118,119]$. The activity of other tubulin-modifying enzymes, such as TTL, is also decreased during tumorigenesis in mouse models, resulting in increased detyrosinatedand $\Delta 2$-tubulin levels [121]. This is consistent with the association between $\alpha$-tubulin detyrosination and tumor aggressiveness [99], as well as with the frequent downregulation of TTL and consequent upregulation of $\alpha$-tubulin detyrosination in several cancers (Table 1).

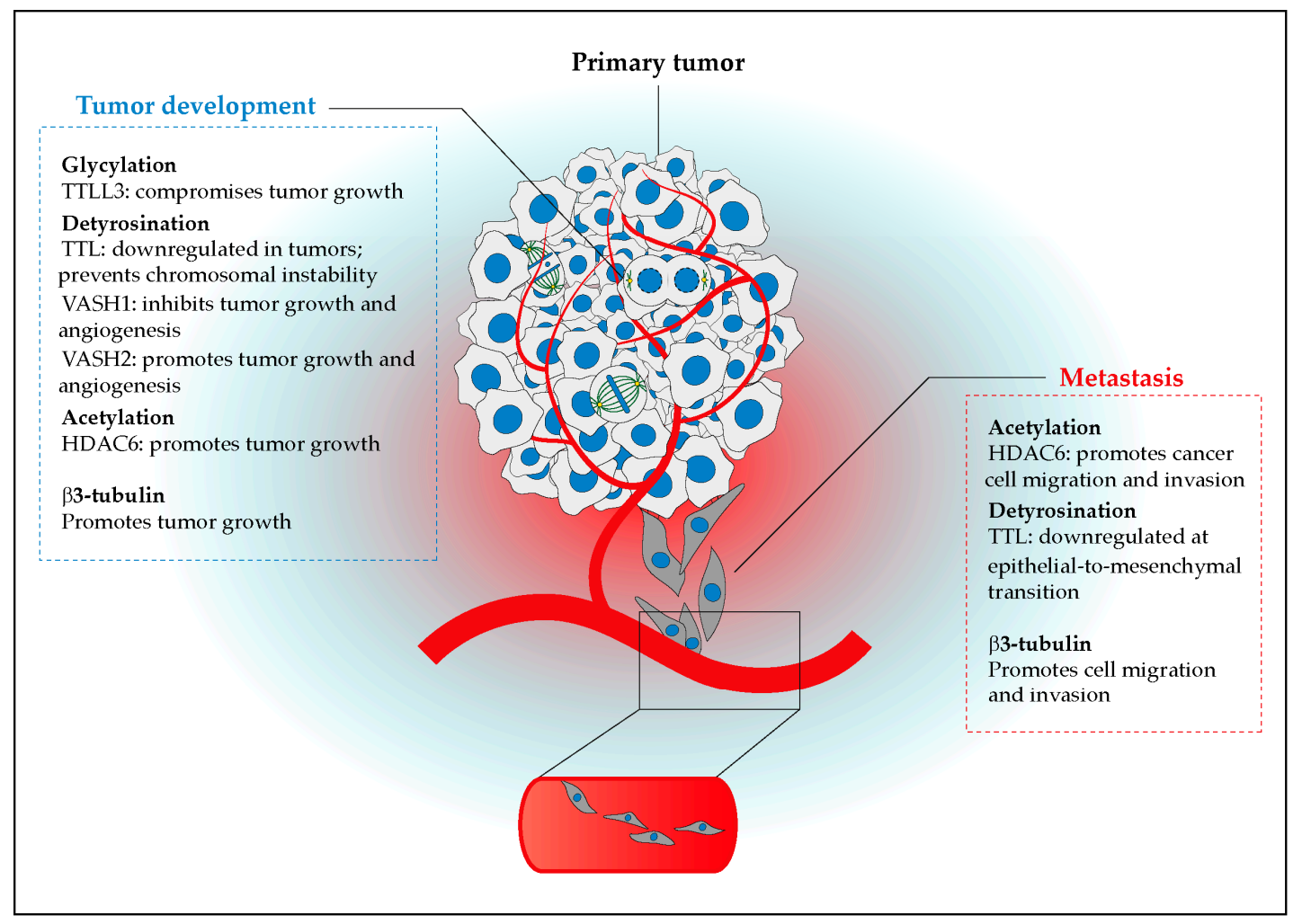

Figure 3. Implications of the tubulin code for tumor progression and metastasis. While the downregulation of TTLL3 (glycylation), together with the expression of VASH2 (detyrosination), HDAC6 (acetylation) and $\beta 3$-tubulin, promotes tumor growth, this is inhibited by VASH1 (detyrosination). Tumor formation and chromosomal instability is also associated with the downregulation of TTL. Tubulin acetylation, detyrosination and $\beta 3$-tubulin isotypes might promote several steps of metastasis associated with the epithelial-to-mesenchymal transition, such as cell migration and invasion. See main text for details.

The recent discovery of Vasohibins (VASH1 and VASH2) as TCPs $[13,14]$ revitalized the discussion about the role of tubulin detyrosination in cancer. Vasohibins and their associated SVBP were originally identified as secreted proteins implicated in angiogenesis [127]. While VASH2 promotes vascularity by accumulating at the sprouting zone, VASH1 expression is increased in endothelial cells of the termination zone, where it inhibits vascularity [128]. During tumor development in mice xenograft models, experiments involving the administration of ectopic VASH1 indicated that it inhibits tumor lymphangiogenesis [129], angiogenesis and growth [130]. On the other hand, VASH2, which appears to play an important role in cancer cell proliferation [124], promotes tumor angiogenesis and growth [124,131-133]. Noteworthy, none of these studies demonstrate that the observed impact in cancer was due to defective tubulin detyrosination. However, human patients suffering from a broad range of carcinomas had mutations in VASH1 and VASH2 that compromised their tubulin detyrosination activity [17] and, more recently, it was suggested that the MT detyrosinating activity 
of VASH1 inhibited angiogenesis by interfering with endocytosis and trafficking of proangiogenic factor receptors [134]. Taken together, these findings suggest that, in addition to the downregulation of TTL [121], the link between tubulin detyrosination and tumorigenesis may be attributed to the role of Vasohibins in angiogenesis. The availability of VASH1/2-SVBP knockout mice $[128,135]$ will be instrumental in clarifying the apparently opposite roles of VASH1 and VASH2 in cancer and whether this is due to their secreted and/or tubulin detyrosinating activities.

Table 1. Tubulin isotypes, post-translational modifications and modifying enzymes in cancer.

\begin{tabular}{|c|c|c|c|}
\hline $\begin{array}{l}\text { Tubulin PTM (and/or } \\
\text { Enzymes)/Isotype }\end{array}$ & Cancer & Regulation & References \\
\hline \multirow{3}{*}{ Detyrosination } & Prostate Cancer Cells & Upregulated & [122] \\
\hline & $\begin{array}{l}\text { Poor Prognosis } \\
\text { Breast Tumors }\end{array}$ & Upregulated & [99] \\
\hline & $\begin{array}{c}\text { Invasive Ductal } \\
\text { Carcinoma (Breast) }\end{array}$ & Upregulated & [123] \\
\hline \multirow[b]{2}{*}{ TTL } & Prostate Cancer Cells & Downregulated & [122] \\
\hline & $\begin{array}{l}\text { Poor Prognosis } \\
\text { Neuroblastomas }\end{array}$ & Downregulated & [100] \\
\hline VASH2 & $\begin{array}{c}\text { Hepatocellular } \\
\text { carcinoma Tissues and } \\
\text { Cell Lines }\end{array}$ & Upregulated & [124] \\
\hline$\Delta 2$-Tubulin & Prostate Cancer Cells & Downregulated & [122] \\
\hline Acetylation & $\begin{array}{l}\text { Metastatic Breast Tumors } \\
\text { and Cell Lines }\end{array}$ & Upregulated & [98] \\
\hline \multirow{3}{*}{ HDAC6 } & Pancreatic Tumors & Upregulated & [125] \\
\hline & $\begin{array}{l}\text { Glioblastoma Tissues } \\
\text { and Cell Lines }\end{array}$ & Upregulated & [118] \\
\hline & $\begin{array}{c}\text { Cholangiocarcinoma } \\
\text { Cell Lines }\end{array}$ & Upregulated & [115] \\
\hline $\begin{array}{l}\text { Glutamylation/ } \\
\text { Polyglutamylation }\end{array}$ & Prostate Cancer Cells & Upregulated & [122] \\
\hline TTLL4 & $\begin{array}{c}\text { Pancreatic Ductal } \\
\text { Adenocarcinoma Cells }\end{array}$ & Upregulated & [111] \\
\hline $\begin{array}{l}\text { Glycylation } \\
\text { TTLL3 }\end{array}$ & $\begin{array}{l}\text { Colon Tumors and } \\
\text { Cell Lines }\end{array}$ & Downregulated & [110] \\
\hline \multirow{3}{*}{$\beta 3$-tubulin } & $\begin{array}{c}\text { Pancreatic Tumors and } \\
\text { Cell Lines }\end{array}$ & Upregulated & [102] \\
\hline & $\begin{array}{c}\text { Pancreatic Ductal } \\
\text { Adenocarcinoma Tissues }\end{array}$ & Upregulated & [126] \\
\hline & $\begin{array}{l}\text { Breast Cancer } \\
\text { Brain Metastases }\end{array}$ & Upregulated & [103] \\
\hline
\end{tabular}

\subsection{The Cancer Tubulin Code in Cell Migration and Invasion}

Tubulin PTMs have also been implicated in epithelial-to-mesenchymal transition (EMT), a key process behind metastasis initiation. For instance, experimental increase of the tubulin deacetylase HDAC6 promoted EMT, whereas TGF- $\beta$ induction of EMT downregulated tubulin acetylation [136]. Likewise, the induction of EMT also correlated with the downregulation of TTL and the consequent increase of tubulin detyrosination [123], as shown before during tumor development [121], thus pointing to the possible involvement of these tubulin PTMs and associated enzymes in cell transformation.

Interestingly, tubulin acetylation is also frequently associated with the regulation of cell migration, although this remains controversial. While HDAC6 expression and activity was proposed to promote cell migration [12,120,136-138], the opposite effect was observed after the loss of $\alpha$ Tat 1 or mutation 
of the $\alpha$-tubulin lysine 40 (K40R) $[98,137,139,140]$. The establishment of cell adhesion to the substrate also has implications for cell motility, and the loss of either HDAC 6 or $\alpha$ Tat1 leads to an increased focal adhesion area and number, respectively, as well as decreased dynamics $[137,141]$. However, other works reported that a loss of $\alpha$ Tat1 leads to a decrease in the focal adhesion number [114]. The basis for this discrepancy remains unclear, but it is likely associated with different experimental setups; one study investigated the role of $\alpha$ Tat1 in wound-induced migrating cells [137], while the other used normally growing cells [114], raising the possibility that $\alpha$ Tat1 promotes focal adhesion dynamics specifically during cell migration.

The upregulation of tubulin acetylation in metastatic breast tumors and cell lines [98] is consistent with its association with cancer cell invasiveness. RNAi-mediated depletion of either $\alpha$ Tat1 or HDAC6 indicated that their expression induced breast cancer cell invasion [139,140,142]. Additionally, the increased tubulin acetylation of these metastatic breast cancer cells promoted micro-tentacle generation and cell reattachment ability, essential for metastasis [98]. Likewise, a high frequency of micro-tentacles and cell reattachment were also associated with tubulin detyrosination [123,143]. Collectively, these data favor a potential role of tubulin acetylation in metastasis progression. While HDAC6 indiscriminately acts upon multiple protein targets, the direct modulation of tubulin acetylation by K40R mutation experiments suggest that the upregulation of tubulin acetylation is a metastasis-promoting factor, supporting the $\alpha$ Tat1-related findings. This would explain the link between the upregulation of tubulin acetylation and poor prognosis in breast cancer patients [98], but unspecific effects due to the overexpression of GFP-tagged K40R mutant $\alpha$-tubulin cannot be excluded.

\section{How Alterations of the Tubulin Code in Mitosis Might Be Implicated in Cancer}

Chromosomal instability, a hallmark of cancers, has been shown to promote the metastatic process [73]. Indeed, the overexpression of Kif2b or MCAK, in addition to reestablishing the stability of chromosomally unstable cancer cells $[55,73]$, inhibits metastasis in vitro and in vivo, with a consequent increase in survival [73]. Given that excessive tubulin detyrosination might lead to chromosomal instability by suppressing the error correction activity of MCAK and Kif2b [37], together with the observed upregulation of tubulin detyrosination in invasive cancer and with poor prognosis (Table 1), it raises the exciting possibility that an increase in tubulin detyrosination might promote cancer progression through inhibition of the mitotic error correction machinery. However, an extensive analysis of tubulin detyrosination in chromosomal instability-prone cancers, together with the elucidation of its implications for cancer metastasis, is necessary for its establishment as potential diagnostic and prognostic biomarkers. In addition, tubulin detyrosination represents a promising therapeutic target for cancer suppression—for example, by using TCP inhibitors, such as epoY [13] or parthenolide [144].

The deregulation of tubulin detyrosination in cancers might also be involved in other mitotic-related cancer features. Firstly, the cell cycle delay observed upon VASH1/2 [19] and VASH2 [124] deletion might unveil the importance of VASH2 for proper cancer cell proliferation and tumor development [124,131-133]. Furthermore, both experimental upregulation and downregulation of tubulin detyrosination led to congression defects, causing alterations in the CENP-E-mediated transport of chromosomes to the spindle equator [36]. Additionally, the decrease of CENP-E expression is well-established to promote mild chromosomal instability and aneuploidy, as well as tumorigenesis in mice [145-148]. Therefore, the deregulation of tubulin detyrosination in cancers (Table 1) may also account for cancer promotion under conditions of moderate chromosomal instability, such as those associated with mild problems in chromosome congression. Further investigation is required to fully understand the potential implications of tubulin detyrosination and other PTMs for tumorigenesis and the respective link with chromosomal instability. 


\section{Conclusions and Outlook}

Since the initial observations implicating tubulin PTMs in cell division, recent works have allowed a deeper understanding of their involvement-in particular, detyrosination/tyrosination - in the coordination of several mechanisms underlying faithful chromosome segregation during mitosis. However, considerable knowledge is still lacking in order to establish a complete picture of the roles played by the tubulin code in mitosis. The scenario is no different regarding the emerging cancer tubulin code, in which a considerable amount of disconnected data dominates. Nevertheless, there are already some promising links between the deregulation of certain tubulin isotypes and PTMs (notoriously, acetylation, detyrosination and glycylation) and several cancers. A more systematic investigation of these links will be of high priority to the field and might prove important for diagnostic and prognostic purposes. This is likely to have a major impact in understanding and mitigating the acquired resistance to microtubule-targeting drugs, the biggest threat in current cancer chemotherapy. Future work is also necessary to establish clear functional links beyond correlations by taking advantage of emerging molecular tools and model systems for the modulation and analysis of tubulin isotypes and PTMs (both in vitro and in vivo) that will strengthen and clarify their potential therapeutic value for the treatment of human cancers.

Author Contributions: Discussed and agreed on the structure of the review, D.L. and H.M.; wrote the first draft of the manuscript, D.L.; prepared the final draft and revised the manuscript upon peer review, H.M. Both authors prepared figures and tables. Both authors have read and agreed to the published version of the manuscript.

Funding: Danilo Lopes is a student of Programa de Pós-Graduação Ciência para o Desenvolvimento (PGCD) from Instituto Gulbenkian de Ciência (IGC), Oeiras, Portugal and recipient of a studentship (SFRH/BD/135077/2017) from Fundação para a Ciência e a Tecnologia of Portugal. Work in the laboratory of H.M. is funded by the European Research Council (ERC) under the European Union's Horizon 2020 Research and Innovation Programme (grant agreement No 681443).

Acknowledgments: We thank Liam Cheeseman for comments and the critical reading of this manuscript.

Conflicts of Interest: The authors declare no conflict of interest.

\section{References}

1. Desai, A.; Mitchison, T.J. Microtubule polymerization dynamics. Annu. Rev. Cell Dev. Biol. 1997, $13,83-117$. [CrossRef] [PubMed]

2. Ludueña, R.F.; Banerjee, A. The isotypes of tubulin. In The Role of Microtubules in Cell Biology, Neurobiology, and Oncology; Springer: Berlin/Heidelberg, Germany, 2008; pp. 123-175.

3. Janke, C. The tubulin code: Molecular components, readout mechanisms, and functions. J. Cell Biol. 2014, 206, 461-472. [CrossRef] [PubMed]

4. Verhey, K.J.; Gaertig, J. The tubulin code. Cell Cycle 2007, 6, 2152-2160. [CrossRef] [PubMed]

5. Janke, C.; Magiera, M.M. The tubulin code and its role in controlling microtubule properties and functions. Nat. Rev. Mol. Cell Biol. 2020, 21, 307-326. [CrossRef]

6. L'Hernault, S.W.; Rosenbaum, J.L. Chlamydomonas alpha-tubulin is posttranslationally modified by acetylation on the epsilon-amino group of a lysine. Biochemistry 1985, 24, 473-478. [CrossRef]

7. Soppina, V.; Herbstman, J.F.; Skiniotis, G.; Verhey, K.J. Luminal localization of $\alpha$-tubulin k40 acetylation by cryo-em analysis of fab-labeled microtubules. PLOS ONE 2012, 7, e48204. [CrossRef]

8. Chu, C.W.; Hou, F.; Zhang, J.; Phu, L.; Loktev, A.V.; Kirkpatrick, D.S.; Jackson, P.K.; Zhao, Y.; Zou, H. A novel acetylation of beta-tubulin by san modulates microtubule polymerization via down-regulating tubulin incorporation. Mol. Biol. Cell 2011, 22, 448-456. [CrossRef]

9. Akella, J.S.; Wloga, D.; Kim, J.; Starostina, N.G.; Lyons-Abbott, S.; Morrissette, N.S.; Dougan, S.T.; Kipreos, E.T.; Gaertig, J. Mec-17 is an alpha-tubulin acetyltransferase. Nature 2010, 467, 218-222. [CrossRef]

10. Shida, T.; Cueva, J.G.; Xu, Z.; Goodman, M.B.; Nachury, M.V. The major alpha-tubulin k40 acetyltransferase alphatat1 promotes rapid ciliogenesis and efficient mechanosensation. Proc. Natl. Acad. Sci. USA 2010, 107, 21517-21522. [CrossRef]

11. North, B.J.; Marshall, B.L.; Borra, M.T.; Denu, J.M.; Verdin, E. The human sir2 ortholog, sirt2, is an nad+-dependent tubulin deacetylase. Mol. Cell 2003, 11, 437-444. [CrossRef] 
12. Hubbert, C.; Guardiola, A.; Shao, R.; Kawaguchi, Y.; Ito, A.; Nixon, A.; Yoshida, M.; Wang, X.F.; Yao, T.P. Hdac6 is a microtubule-associated deacetylase. Nature 2002, 417, 455-458. [CrossRef]

13. Aillaud, C.; Bosc, C.; Peris, L.; Bosson, A.; Heemeryck, P.; Van Dijk, J.; Le Friec, J.; Boulan, B.; Vossier, F.; Sanman, L.E.; et al. Vasohibins/svbp are tubulin carboxypeptidases (tcps) that regulate neuron differentiation. Science 2017, 358, 1448-1453. [CrossRef] [PubMed]

14. Nieuwenhuis, J.; Adamopoulos, A.; Bleijerveld, O.B.; Mazouzi, A.; Stickel, E.; Celie, P.; Altelaar, M.; Knipscheer, P.; Perrakis, A.; Blomen, V.A.; et al. Vasohibins encode tubulin detyrosinating activity. Science 2017, 358, 1453-1456. [CrossRef]

15. Li, F.; Li, Y.; Ye, X.; Gao, H.; Shi, Z.; Luo, X.; Rice, L.M.; Yu, H. Cryo-em structure of vash1-svbp bound to microtubules. eLife 2020, 9, e58157. [CrossRef] [PubMed]

16. Liu, X.; Wang, H.; Zhu, J.; Xie, Y.; Liang, X.; Chen, Z.; Feng, Y.; Zhang, Y. Structural insights into tubulin detyrosination by vasohibins-svbp complex. Cell Discov. 2019, 5, 65. [CrossRef]

17. Wang, N.; Bosc, C.; Ryul Choi, S.; Boulan, B.; Peris, L.; Olieric, N.; Bao, H.; Krichen, F.; Chen, L.; Andrieux, A.; et al. Structural basis of tubulin detyrosination by the vasohibin-svbp enzyme complex. Nat. Struct. Mol. Biol. 2019, 26, 571-582. [CrossRef]

18. Li, F.; Hu, Y.; Qi, S.; Luo, X.; Yu, H. Structural basis of tubulin detyrosination by vasohibins. Nat. Struct. Mol. Biol. 2019, 26, 583-591. [CrossRef]

19. Liao, S.; Rajendraprasad, G.; Wang, N.; Eibes, S.; Gao, J.; Yu, H.; Wu, G.; Tu, X.; Huang, H.; Barisic, M.; et al. Molecular basis of vasohibins-mediated detyrosination and its impact on spindle function and mitosis. Cell Res. 2019, 29, 533-547. [CrossRef]

20. Ersfeld, K.; Wehland, J.; Plessmann, U.; Dodemont, H.; Gerke, V.; Weber, K. Characterization of the tubulin-tyrosine ligase. J. Cell Biol. 1993, 120, 725-732. [CrossRef] [PubMed]

21. Schroder, H.C.; Wehland, J.; Weber, K. Purification of brain tubulin-tyrosine ligase by biochemical and immunological methods. J. Cell Biol. 1985, 100, 276-281. [CrossRef] [PubMed]

22. Rogowski, K.; van Dijk, J.; Magiera, M.M.; Bosc, C.; Deloulme, J.C.; Bosson, A.; Peris, L.; Gold, N.D.; Lacroix, B.; Bosch Grau, M.; et al. A family of protein-deglutamylating enzymes associated with neurodegeneration. Cell 2010, 143, 564-578. [CrossRef]

23. Tort, O.; Tanco, S.; Rocha, C.; Bieche, I.; Seixas, C.; Bosc, C.; Andrieux, A.; Moutin, M.J.; Aviles, F.X.; Lorenzo, J.; et al. The cytosolic carboxypeptidases cсp2 and ccp3 catalyze posttranslational removal of acidic amino acids. Mol. Biol. Cell 2014, 25, 3017-3027. [CrossRef] [PubMed]

24. Paturle-Lafanechere, L.; Edde, B.; Denoulet, P.; Van Dorsselaer, A.; Mazarguil, H.; Le Caer, J.P.; Wehland, J.; Job, D. Characterization of a major brain tubulin variant which cannot be tyrosinated. Biochemistry 1991, 30, 10523-10528. [CrossRef] [PubMed]

25. Aillaud, C.; Bosc, C.; Saoudi, Y.; Denarier, E.; Peris, L.; Sago, L.; Taulet, N.; Cieren, A.; Tort, O.; Magiera, M.M.; et al. Evidence for new c-terminally truncated variants of alpha- and beta-tubulins. Mol. Biol. Cell 2016, 27, 640-653. [CrossRef]

26. Edde, B.; Rossier, J.; Le Caer, J.P.; Desbruyeres, E.; Gros, F.; Denoulet, P. Posttranslational glutamylation of alpha-tubulin. Science 1990, 247, 83-85. [CrossRef]

27. Redeker, V.; Levilliers, N.; Schmitter, J.M.; Le Caer, J.P.; Rossier, J.; Adoutte, A.; Bre, M.H. Polyglycylation of tubulin: A posttranslational modification in axonemal microtubules. Science 1994, 266, 1688-1691. [CrossRef] [PubMed]

28. Janke, C.; Rogowski, K.; Wloga, D.; Regnard, C.; Kajava, A.V.; Strub, J.M.; Temurak, N.; van Dijk, J.; Boucher, D.; van Dorsselaer, A.; et al. Tubulin polyglutamylase enzymes are members of the ttl domain protein family. Science 2005, 308, 1758-1762. [CrossRef]

29. Van Dijk, J.; Rogowski, K.; Miro, J.; Lacroix, B.; Edde, B.; Janke, C. A targeted multienzyme mechanism for selective microtubule polyglutamylation. Mol. Cell 2007, 26, 437-448. [CrossRef]

30. Kimura, Y.; Kurabe, N.; Ikegami, K.; Tsutsumi, K.; Konishi, Y.; Kaplan, O.I.; Kunitomo, H.; Iino, Y.; Blacque, O.E.; Setou, M. Identification of tubulin deglutamylase among caenorhabditis elegans and mammalian cytosolic carboxypeptidases (ccps). J. Biol. Chem. 2010, 285, 22936-22941. [CrossRef]

31. Rogowski, K.; Juge, F.; van Dijk, J.; Wloga, D.; Strub, J.M.; Levilliers, N.; Thomas, D.; Bre, M.H.; Van Dorsselaer, A.; Gaertig, J.; et al. Evolutionary divergence of enzymatic mechanisms for posttranslational polyglycylation. Cell 2009, 137, 1076-1087. [CrossRef] 
32. Wloga, D.; Webster, D.M.; Rogowski, K.; Bre, M.H.; Levilliers, N.; Jerka-Dziadosz, M.; Janke, C.; Dougan, S.T.; Gaertig, J. Ttll3 is a tubulin glycine ligase that regulates the assembly of cilia. Dev. Cell 2009, 16, 867-876. [CrossRef] [PubMed]

33. Walgren, J.L.; Vincent, T.S.; Schey, K.L.; Buse, M.G. High glucose and insulin promote o-glcnac modification of proteins, including alpha-tubulin. Am. J. Physiol. Endocrinol. Metab. 2003, 284, E424-E434. [CrossRef] [PubMed]

34. Tian, J.L.; Qin, H. O-glcnacylation regulates primary ciliary length by promoting microtubule disassembly. iScience 2019, 12, 379-391. [CrossRef] [PubMed]

35. Ji, S.; Kang, J.G.; Park, S.Y.; Lee, J.; Oh, Y.J.; Cho, J.W. O-glcnacylation of tubulin inhibits its polymerization. Amino Acids 2011, 40, 809-818. [CrossRef]

36. Barisic, M.; Silva e Sousa, R.; Tripathy, S.K.; Magiera, M.M.; Zaytsev, A.V.; Pereira, A.L.; Janke, C.; Grishchuk, E.L.; Maiato, H. Mitosis. Microtubule detyrosination guides chromosomes during mitosis. Science 2015, 348, 799-803. [CrossRef]

37. Ferreira, L.T.; Orr, B.; Rajendraprasad, G.; Pereira, A.J.; Lemos, C.; Lima, J.T.; Guasch Boldu, C.; Ferreira, J.G.; Barisic, M.; Maiato, H. Alpha-tubulin detyrosination impairs mitotic error correction by suppressing mcak centromeric activity. J. Cell Biol. 2020, 219, e201910064. [CrossRef]

38. Gundersen, G.G.; Bulinski, J.C. Distribution of tyrosinated and nontyrosinated alpha-tubulin during mitosis. J. Cell Biol. 1986, 102, 1118-1126. [CrossRef]

39. Gundersen, G.G.; Kalnoski, M.H.; Bulinski, J.C. Distinct populations of microtubules: Tyrosinated and nontyrosinated alpha tubulin are distributed differently in vivo. Cell 1984, 38, 779-789. [CrossRef]

40. Peris, L.; Thery, M.; Faure, J.; Saoudi, Y.; Lafanechere, L.; Chilton, J.K.; Gordon-Weeks, P.; Galjart, N.; Bornens, M.; Wordeman, L.; et al. Tubulin tyrosination is a major factor affecting the recruitment of cap-gly proteins at microtubule plus ends. J. Cell Biol. 2006, 174, 839-849. [CrossRef]

41. Wilson, P.J.; Forer, A. Acetylated alpha-tubulin in spermatogenic cells of the crane fly nephrotoma-suturalis-kinetochore microtubules are selectively acetylated. Cell Motil. Cytoskelet. 1989, 14, 237-250. [CrossRef]

42. Bobinnec, Y.; Moudjou, M.; Fouquet, J.P.; Desbruyeres, E.; Edde, B.; Bornens, M. Glutamylation of centriole and cytoplasmic tubulin in proliferating non-neuronal cells. Cell Motil. Cytoskelet. 1998, 39, $223-232$. [CrossRef]

43. Ferreira, L.T.; Figueiredo, A.C.; Orr, B.; Lopes, D.; Maiato, H. Dissecting the role of the tubulin code in mitosis. In Methods in Cell Biology; Elsevier: Amsterdam, The Netherlands, 2018; Volume 144, pp. 33-74.

44. Maiato, H.; Sampaio, P.; Sunkel, C.E. Microtubule-associated proteins and their essential roles during mitosis. Int. Rev. Cytol. 2004, 241, 53-153.

45. Cross, R.A.; McAinsh, A. Prime movers: The mechanochemistry of mitotic kinesins. Nat. Rev. 2014, 15, 257-271. [CrossRef] [PubMed]

46. Yang, Z.; Tulu, U.S.; Wadsworth, P.; Rieder, C.L. Kinetochore dynein is required for chromosome motion and congression independent of the spindle checkpoint. Curr. Biol. 2007, 17, 973-980. [CrossRef]

47. Hayden, J.H.; Bowser, S.S.; Rieder, C.L. Kinetochores capture astral microtubules during chromosome attachment to the mitotic spindle: Direct visualization in live newt lung cells. J. Cell Biol. 1990, 111, 1039-1045. [CrossRef]

48. Li, Y.; Yu, W.; Liang, Y.; Zhu, X. Kinetochore dynein generates a poleward pulling force to facilitate congression and full chromosome alignment. Cell Res. 2007, 17, 701-712. [CrossRef] [PubMed]

49. Vorozhko, V.V.; Emanuele, M.J.; Kallio, M.J.; Stukenberg, P.T.; Gorbsky, G.J. Multiple mechanisms of chromosome movement in vertebrate cells mediated through the ndc80 complex and dynein/dynactin. Chromosoma 2008, 117, 169-179. [CrossRef]

50. Pfarr, C.M.; Coue, M.; Grissom, P.M.; Hays, T.S.; Porter, M.E.; McIntosh, J.R. Cytoplasmic dynein is localized to kinetochores during mitosis. Nature 1990, 345, 263-265. [CrossRef]

51. Steuer, E.R.; Wordeman, L.; Schroer, T.A.; Sheetz, M.P. Localization of cytoplasmic dynein to mitotic spindles and kinetochores. Nature 1990, 345, 266-268. [CrossRef]

52. Kapoor, T.M.; Lampson, M.A.; Hergert, P.; Cameron, L.; Cimini, D.; Salmon, E.D.; McEwen, B.F.; Khodjakov, A. Chromosomes can congress to the metaphase plate before biorientation. Science 2006, 311, 388-391. [CrossRef] [PubMed] 
53. Wood, K.W.; Sakowicz, R.; Goldstein, L.S.; Cleveland, D.W. Cenp-e is a plus end-directed kinetochore motor required for metaphase chromosome alignment. Cell 1997, 91, 357-366. [CrossRef]

54. Mann, B.J.; Wadsworth, P. Kinesin-5 regulation and function in mitosis. Trends Cell Biol. 2019, $29,66-79$. [CrossRef]

55. Bakhoum, S.F.; Thompson, S.L.; Manning, A.L.; Compton, D.A. Genome stability is ensured by temporal control of kinetochore-microtubule dynamics. Nat. Cell Biol. 2009, 11, 27-35. [CrossRef] [PubMed]

56. Kline-Smith, S.L.; Khodjakov, A.; Hergert, P.; Walczak, C.E. Depletion of centromeric mcak leads to chromosome congression and segregation defects due to improper kinetochore attachments. Mol. Biol. Cell 2004, 15, 1146-1159. [CrossRef]

57. Lan, W.; Zhang, X.; Kline-Smith, S.L.; Rosasco, S.E.; Barrett-Wilt, G.A.; Shabanowitz, J.; Hunt, D.F.; Walczak, C.E.; Stukenberg, P.T. Aurora b phosphorylates centromeric mcak and regulates its localization and microtubule depolymerization activity. Curr. Biol. 2004, 14, 273-286. [CrossRef] [PubMed]

58. Andrews, P.D.; Ovechkina, Y.; Morrice, N.; Wagenbach, M.; Duncan, K.; Wordeman, L.; Swedlow, J.R. Aurora b regulates mcak at the mitotic centromere. Dev. Cell 2004, 6, 253-268. [CrossRef]

59. Domnitz, S.B.; Wagenbach, M.; Decarreau, J.; Wordeman, L. Mcak activity at microtubule tips regulates spindle microtubule length to promote robust kinetochore attachment. J. Cell Biol. 2012, 197, 231-237. [CrossRef]

60. Reed, N.A.; Cai, D.; Blasius, T.L.; Jih, G.T.; Meyhofer, E.; Gaertig, J.; Verhey, K.J. Microtubule acetylation promotes kinesin-1 binding and transport. Curr. Biol. 2006, 16, 2166-2172. [CrossRef]

61. Konishi, Y.; Setou, M. Tubulin tyrosination navigates the kinesin-1 motor domain to axons. Nat. Neurosci. 2009, 12, 559-567. [CrossRef]

62. McKenney, R.J.; Huynh, W.; Tanenbaum, M.E.; Bhabha, G.; Vale, R.D. Activation of cytoplasmic dynein motility by dynactin-cargo adapter complexes. Science 2014, 345, 337-341. [CrossRef]

63. McKenney, R.J.; Huynh, W.; Vale, R.D.; Sirajuddin, M. Tyrosination of alpha-tubulin controls the initiation of processive dynein-dynactin motility. EMBO J. 2016, 35, 1175-1185. [CrossRef]

64. Nirschl, J.J.; Magiera, M.M.; Lazarus, J.E.; Janke, C.; Holzbaur, E.L. Alpha-tubulin tyrosination and clip-170 phosphorylation regulate the initiation of dynein-driven transport in neurons. Cell Rep. 2016, 14, 2637-2652. [CrossRef] [PubMed]

65. Barisic, M.; Maiato, H. The tubulin code: A navigation system for chromosomes during mitosis. Trends Cell Biol. 2016, 26, 766-775. [CrossRef]

66. Barisic, M.; Aguiar, P.; Geley, S.; Maiato, H. Kinetochore motors drive congression of peripheral polar chromosomes by overcoming random arm-ejection forces. Nat. Cell Biol. 2014, 16, 1249-1256. [CrossRef]

67. Chmatal, L.; Yang, K.; Schultz, R.M.; Lampson, M.A. Spatial regulation of kinetochore microtubule attachments by destabilization at spindle poles in meiosis i. Curr. Biol. 2015, 25, 1835-1841. [CrossRef] [PubMed]

68. Ye, A.A.; Deretic, J.; Hole, C.M.; Hinman, A.W.; Cimini, D.; Welburn, J.P.; Maresca, T.J. Aurora a kinase contributes to a pole-based error correction pathway. Curr. Biol. 2015, 25, 1842-1851. [CrossRef]

69. Kim, Y.; Holland, A.J.; Lan, W.; Cleveland, D.W. Aurora kinases and protein phosphatase 1 mediate chromosome congression through regulation of cenp-e. Cell 2010, 142, 444-455. [CrossRef] [PubMed]

70. Pereira, A.; Sousa, M.; Almeida, A.C.; Ferreira, L.T.; Costa, A.R.; Novais-Cruz, M.; Ferras, C.; Sousa, M.M.; Sampaio, P.; Belsley, M.; et al. Coherent-hybrid sted: High contrast sub-diffraction imaging using a bi-vortex depletion beam. Opt. Express 2019, 27, 8092-8111. [CrossRef]

71. Steblyanko, Y.; Rajendraprasad, G.; Osswald, M.; Eibes, S.; Jacome, A.; Geley, S.; Pereira, A.J.; Maiato, H.; Barisic, M. Microtubule poleward flux in human cells is driven by the coordinated action of four kinesins. EMBO J. 2020, e105432. [CrossRef]

72. Bakhoum, S.F.; Genovese, G.; Compton, D.A. Deviant kinetochore microtubule dynamics underlie chromosomal instability. Curr. Biol. 2009, 19, 1937-1942. [CrossRef]

73. Bakhoum, S.F.; Ngo, B.; Laughney, A.M.; Cavallo, J.A.; Murphy, C.J.; Ly, P.; Shah, P.; Sriram, R.K.; Watkins, T.B.K.; Taunk, N.K.; et al. Chromosomal instability drives metastasis through a cytosolic DNA response. Nature 2018, 553, 467-472. [CrossRef] [PubMed]

74. Peris, L.; Wagenbach, M.; Lafanechere, L.; Brocard, J.; Moore, A.T.; Kozielski, F.; Job, D.; Wordeman, L.; Andrieux, A. Motor-dependent microtubule disassembly driven by tubulin tyrosination. J. Cell Biol. 2009, 185, 1159-1166. [CrossRef] [PubMed] 
75. Sirajuddin, M.; Rice, L.M.; Vale, R.D. Regulation of microtubule motors by tubulin isotypes and post-translational modifications. Nat. Cell Biol. 2014, 16, 335-344. [CrossRef]

76. Silkworth, W.T.; Nardi, I.K.; Paul, R.; Mogilner, A.; Cimini, D. Timing of centrosome separation is important for accurate chromosome segregation. Mol. Biol. Cell 2012, 23, 401-411. [CrossRef]

77. Nunes, V.; Dantas, M.; Castro, D.; Vitiello, E.; Wang, I.; Carpi, N.; Balland, M.; Piel, M.; Aguiar, P.; Maiato, H.; et al. Centrosome-nuclear axis repositioning drives the assembly of a bipolar spindle scaffold to ensure mitotic fidelity. Mol. Biol. Cell 2020, 31, 1675-1690. [CrossRef]

78. Raaijmakers, J.A.; van Heesbeen, R.G.H.P.; Meaders, J.L.; Geers, E.F.; Fernandez-Garcia, B.; Medema, R.H.; Tanenbaum, M.E. Nuclear envelope-associated dynein drives prophase centrosome separation and enables eg5-independent bipolar spindle formation. EMBO J. 2012, 31, 4179-4190. [CrossRef]

79. Kahn, O.I.; Sharma, V.; Gonzalez-Billault, C.; Baas, P.W. Effects of kinesin-5 inhibition on dendritic architecture and microtubule organization. Mol. Biol. Cell 2015, 26, 66-77. [CrossRef]

80. Siller, K.H.; Doe, C.Q. Spindle orientation during asymmetric cell division. Nat. Cell Biol. 2009, 11, 365-374. [CrossRef]

81. Kotak, S.; Busso, C.; Gonczy, P. Cortical dynein is critical for proper spindle positioning in human cells. J. Cell Biol. 2012, 199, 97-110. [CrossRef]

82. Nguyen-Ngoc, T.; Afshar, K.; Gonczy, P. Coupling of cortical dynein and g alpha proteins mediates spindle positioning in caenorhabditis elegans. Nat. Cell Biol. 2007, 9, 1294-1302. [CrossRef] [PubMed]

83. Barbosa, D.J.; Duro, J.; Prevo, B.; Cheerambathur, D.K.; Carvalho, A.X.; Gassmann, R. Dynactin binding to tyrosinated microtubules promotes centrosome centration in c. Elegans by enhancing dynein-mediated organelle transport. PLoS Genet. 2017, 13, e1006941. [CrossRef]

84. Bobinnec, Y.; Khodjakov, A.; Mir, L.M.; Rieder, C.L.; Edde, B.; Bornens, M. Centriole disassembly in vivo and its effect on centrosome structure and function in vertebrate cells. J. Cell Biol. 1998, 143, 1575-1589. [CrossRef] [PubMed]

85. Abal, M.; Keryer, G.; Bornens, M. Centrioles resist forces applied on centrosomes during g2/m transition. Biol. Cell 2005, 97, 425-434. [CrossRef] [PubMed]

86. Mahecic, D.; Gambarotto, D.; Douglass, K.M.; Fortun, D.; Banterle, N.; Ibrahim, K.A.; Le Guennec, M.; Gonczy, P.; Hamel, V.; Guichard, P.; et al. Homogeneous multifocal excitation for high-throughput super-resolution imaging. Nat. Methods 2020, 17, 726-733. [CrossRef] [PubMed]

87. Lacroix, B.; van Dijk, J.; Gold, N.D.; Guizetti, J.; Aldrian-Herrada, G.; Rogowski, K.; Gerlich, D.W.; Janke, C. Tubulin polyglutamylation stimulates spastin-mediated microtubule severing. J. Cell Biol. 2010, 189, 945-954. [CrossRef]

88. Sharma, N.; Bryant, J.; Wloga, D.; Donaldson, R.; Davis, R.C.; Jerka-Dziadosz, M.; Gaertig, J. Katanin regulates dynamics of microtubules and biogenesis of motile cilia. J. Cell Biol. 2007, 178, 1065-1079. [CrossRef]

89. Shin, S.C.; Im, S.K.; Jang, E.H.; Jin, K.S.; Hur, E.M.; Kim, E.E. Structural and molecular basis for katanin-mediated severing of glutamylated microtubules. Cell Rep. 2019, 26, 1357-1367. [CrossRef]

90. Valenstein, M.L.; Roll-Mecak, A. Graded control of microtubule severing by tubulin glutamylation. Cell 2016, 164, 911-921. [CrossRef]

91. Jiang, K.; Rezabkova, L.; Hua, S.S.; Liu, Q.Y.; Capitani, G.; Altelaar, A.F.M.; Heck, A.J.R.; Kammerer, R.A.; Steinmetz, M.O.; Akhmanova, A. Microtubule minus-end regulation at spindle poles by an aspm-katanin complex. Nat. Cell Biol. 2017, 19, 873. [CrossRef]

92. McNally, K.; Audhya, A.; Oegema, K.; McNally, F.J. Katanin controls mitotic and meiotic spindle length. J. Cell Biol. 2006, 175, 881-891. [CrossRef]

93. Zhang, D.; Rogers, G.C.; Buster, D.W.; Sharp, D.J. Three microtubule severing enzymes contribute to the "pacman-flux" machinery that moves chromosomes. J. Cell Biol. 2007, 177, 231-242. [CrossRef]

94. Connell, J.W.; Lindon, C.; Luzio, J.P.; Reid, E. Spastin couples microtubule severing to membrane traffic in completion of cytokinesis and secretion. Traffic 2009, 10, 42-56. [CrossRef]

95. Guizetti, J.; Schermelleh, L.; Mantler, J.; Maar, S.; Poser, I.; Leonhardt, H.; Muller-Reichert, T.; Gerlich, D.W. Cortical constriction during abscission involves helices of escrt-iii-dependent filaments. Science 2011, 331, 1616-1620. [CrossRef]

96. Matsuo, M.; Shimodaira, T.; Kasama, T.; Hata, Y.; Echigo, A.; Okabe, M.; Arai, K.; Makino, Y.; Niwa, S.I.; Saya, H.; et al. Katanin p60 contributes to microtubule instability around the midbody and facilitates cytokinesis in rat cells. PLOS ONE 2013, 8, e80392. [CrossRef] 
97. Thazhath, R.; Liu, C.B.; Gaertig, J. Polyglycylation domain of beta-tubulin maintains axonemal architecture and affects cytokinesis in tetrahymena. Nat. Cell Biol. 2002, 4, 256-259. [CrossRef] [PubMed]

98. Boggs, A.E.; Vitolo, M.I.; Whipple, R.A.; Charpentier, M.S.; Goloubeva, O.G.; Ioffe, O.B.; Tuttle, K.C.; Slovic, J.; Lu, Y.; Mills, G.B.; et al. Alpha-tubulin acetylation elevated in metastatic and basal-like breast cancer cells promotes microtentacle formation, adhesion, and invasive migration. Cancer Res. 2015, 75, $203-215$. [CrossRef] [PubMed]

99. Mialhe, A.; Lafanechere, L.; Treilleux, I.; Peloux, N.; Dumontet, C.; Bremond, A.; Panh, M.H.; Payan, R.; Wehland, J.; Margolis, R.L.; et al. Tubulin detyrosination is a frequent occurrence in breast cancers of poor prognosis. Cancer Res. 2001, 61, 5024-5027.

100. Kato, C.; Miyazaki, K.; Nakagawa, A.; Ohira, M.; Nakamura, Y.; Ozaki, T.; Imai, T.; Nakagawara, A. Low expression of human tubulin tyrosine ligase and suppressed tubulin tyrosination/detyrosination cycle are associated with impaired neuronal differentiation in neuroblastomas with poor prognosis. Int. J. Cancer 2004, 112, 365-375. [CrossRef]

101. Soucek, K.; Kamaid, A.; Phung, A.D.; Kubala, L.; Bulinski, J.C.; Harper, R.W.; Eiserich, J.P. Normal and prostate cancer cells display distinct molecular profiles of alpha-tubulin posttranslational modifications. Prostate 2006, 66, 954-965. [CrossRef] [PubMed]

102. Whipple, R.A.; Matrone, M.A.; Cho, E.H.; Balzer, E.M.; Vitolo, M.I.; Yoon, J.R.; Ioffe, O.B.; Tuttle, K.C.; Yang, J.; Martin, S.S. Epithelial-to-mesenchymal transition promotes tubulin detyrosination and microtentacles that enhance endothelial engagement. Cancer Res. 2010, 70, 8127-8137. [CrossRef]

103. Xue, X.; Gao, W.; Sun, B.; Xu, Y.; Han, B.; Wang, F.; Zhang, Y.; Sun, J.; Wei, J.; Lu, Z.; et al. Vasohibin 2 is transcriptionally activated and promotes angiogenesis in hepatocellular carcinoma. Oncogene 2013, 32, 1724-1734. [CrossRef] [PubMed]

104. Li, D.W.; Sun, X.D.; Zhang, L.L.; Yan, B.; Xie, S.B.; Liu, R.M.; Liu, M.; Zhou, J. Histone deacetylase 6 and cytoplasmic linker protein 170 function together to regulate the motility of pancreatic cancer cells. Protein Cell 2014, 5, 214-223. [CrossRef] [PubMed]

105. Wang, Z.; Hu, P.; Tang, F.; Lian, H.; Chen, X.; Zhang, Y.; He, X.; Liu, W.; Xie, C. Hdac6 promotes cell proliferation and confers resistance to temozolomide in glioblastoma. Cancer Lett. 2016, 379, 134-142. [CrossRef]

106. Gradilone, S.A.; Radtke, B.N.; Bogert, P.S.; Huang, B.Q.; Gajdos, G.B.; LaRusso, N.F. Hdac6 inhibition restores ciliary expression and decreases tumor growth. Cancer Res. 2013, 73, 2259-2270. [CrossRef] [PubMed]

107. Kashiwaya, K.; Nakagawa, H.; Hosokawa, M.; Mochizuki, Y.; Ueda, K.; Piao, L.; Chung, S.; Hamamoto, R.; Eguchi, H.; Ohigashi, H.; et al. Involvement of the tubulin tyrosine ligase-like family member 4 polyglutamylase in pelp1 polyglutamylation and chromatin remodeling in pancreatic cancer cells. Cancer Res. 2010, 70, 4024-4033. [CrossRef] [PubMed]

108. Rocha, C.; Papon, L.; Cacheux, W.; Marques Sousa, P.; Lascano, V.; Tort, O.; Giordano, T.; Vacher, S.; Lemmers, B.; Mariani, P.; et al. Tubulin glycylases are required for primary cilia, control of cell proliferation and tumor development in colon. EMBO J. 2014, 33, 2247-2260. [CrossRef]

109. McCarroll, J.A.; Sharbeen, G.; Liu, J.; Youkhana, J.; Goldstein, D.; McCarthy, N.; Limbri, L.F.; Dischl, D.; Ceyhan, G.O.; Erkan, M.; et al. Betaiii-tubulin: A novel mediator of chemoresistance and metastases in pancreatic cancer. Oncotarget 2015, 6, 2235-2249. [CrossRef] [PubMed]

110. Lee, K.M.; Cao, D.; Itami, A.; Pour, P.M.; Hruban, R.H.; Maitra, A.; Ouellette, M.M. Class iii beta-tubulin, a marker of resistance to paclitaxel, is overexpressed in pancreatic ductal adenocarcinoma and intraepithelial neoplasia. Histopathology 2007, 51, 539-546. [CrossRef]

111. Kanojia, D.; Morshed, R.A.; Zhang, L.; Miska, J.M.; Qiao, J.; Kim, J.W.; Pytel, P.; Balyasnikova, I.V.; Lesniak, M.S.; Ahmed, A.U. Betaiii-tubulin regulates breast cancer metastases to the brain. Mol. Cancer Ther. 2015, 14, 1152-1161. [CrossRef]

112. McCarroll, J.A.; Gan, P.P.; Liu, M.; Kavallaris, M. Betaiii-tubulin is a multifunctional protein involved in drug sensitivity and tumorigenesis in non-small cell lung cancer. Cancer Res. 2010, 70, 4995-5003. [CrossRef]

113. Ferrandina, G.; Zannoni, G.F.; Martinelli, E.; Paglia, A.; Gallotta, V.; Mozzetti, S.; Scambia, G.; Ferlini, C. Class ii beta-tubulin overexpression is a marker of poor clinical outcome in advanced ovarian cancer patients. Clin. Cancer Res. 2006, 12, 2774-2779. [CrossRef] [PubMed] 
114. Ruksha, K.; Mezheyeuski, A.; Nerovnya, A.; Bich, T.; Tur, G.; Gorgun, J.; Luduena, R.; Portyanko, A. Over-expression of betaii-tubulin and especially its localization in cell nuclei correlates with poorer outcomes in colorectal cancer. Cells 2019, 8, 25. [CrossRef] [PubMed]

115. Parker, A.L.; Teo, W.S.; McCarroll, J.A.; Kavallaris, M. An emerging role for tubulin isotypes in modulating cancer biology and chemotherapy resistance. Int. J. Mol. Sci. 2017, 18, 1434. [CrossRef] [PubMed]

116. Panda, D.; Miller, H.P.; Banerjee, A.; Luduena, R.F.; Wilson, L. Microtubule dynamics in vitro are regulated by the tubulin isotype composition. Proc. Natl. Acad. Sci. USA 1994, 91, 11358-11362. [CrossRef]

117. Pamula, M.C.; Ti, S.C.; Kapoor, T.M. The structured core of human beta tubulin confers isotype-specific polymerization properties. J. Cell Biol. 2016, 213, 425-433. [CrossRef]

118. Ti, S.C.; Alushin, G.M.; Kapoor, T.M. Human beta-tubulin isotypes can regulate microtubule protofilament number and stability. Dev. Cell 2018, 47, 175-190 e175. [CrossRef]

119. Van Dijk, J.; Miro, J.; Strub, J.M.; Lacroix, B.; van Dorsselaer, A.; Edde, B.; Janke, C. Polyglutamylation is a post-translational modification with a broad range of substrates. J. Biol. Chem. 2008, 283, 3915-3922. [CrossRef]

120. Regnard, C.; Desbruyeres, E.; Huet, J.C.; Beauvallet, C.; Pernollet, J.C.; Edde, B. Polyglutamylation of nucleosome assembly proteins. J. Biol. Chem. 2000, 275, 15969-15976. [CrossRef]

121. Aguilar, A.; Becker, L.; Tedeschi, T.; Heller, S.; Iomini, C.; Nachury, M.V. Alpha-tubulin k40 acetylation is required for contact inhibition of proliferation and cell-substrate adhesion. Mol. Biol. Cell 2014, 25, 1854-1866. [CrossRef]

122. Lee, Y.S.; Lim, K.H.; Guo, X.; Kawaguchi, Y.; Gao, Y.; Barrientos, T.; Ordentlich, P.; Wang, X.F.; Counter, C.M.; Yao, T.P. The cytoplasmic deacetylase hdac6 is required for efficient oncogenic tumorigenesis. Cancer Res. 2008, 68, 7561-7569. [CrossRef]

123. Putcha, P.; Yu, J.; Rodriguez-Barrueco, R.; Saucedo-Cuevas, L.; Villagrasa, P.; Murga-Penas, E.; Quayle, S.N.; Yang, M.; Castro, V.; Llobet-Navas, D.; et al. Hdac6 activity is a non-oncogene addiction hub for inflammatory breast cancers. Breast Cancer Res. 2015, 17, 149. [CrossRef] [PubMed]

124. Woan, K.V.; Lienlaf, M.; Perez-Villaroel, P.; Lee, C.; Cheng, F.; Knox, T.; Woods, D.M.; Barrios, K.; Powers, J.; Sahakian, E.; et al. Targeting histone deacetylase 6 mediates a dual anti-melanoma effect: Enhanced antitumor immunity and impaired cell proliferation. Mol. Oncol. 2015, 9, 1447-1457. [CrossRef] [PubMed]

125. Zhang, X.; Yuan, Z.; Zhang, Y.; Yong, S.; Salas-Burgos, A.; Koomen, J.; Olashaw, N.; Parsons, J.T.; Yang, X.J.; Dent, S.R.; et al. Hdac6 modulates cell motility by altering the acetylation level of cortactin. Mol. Cell 2007, 27, 197-213. [CrossRef]

126. Lafanechere, L.; Courtay-Cahen, C.; Kawakami, T.; Jacrot, M.; Rudiger, M.; Wehland, J.; Job, D.; Margolis, R.L. Suppression of tubulin tyrosine ligase during tumor growth. J. Cell Sci. 1998, 111 Pt 2, 171-181.

127. Sato, Y. The vasohibin family: A novel family for angiogenesis regulation. J. Biochem. 2013, 153, 5-11. [CrossRef]

128. Kimura, H.; Miyashita, H.; Suzuki, Y.; Kobayashi, M.; Watanabe, K.; Sonoda, H.; Ohta, H.; Fujiwara, T.; Shimosegawa, T.; Sato, Y. Distinctive localization and opposed roles of vasohibin-1 and vasohibin-2 in the regulation of angiogenesis. Blood 2009, 113, 4810-4818. [CrossRef] [PubMed]

129. Heishi, T.; Hosaka, T.; Suzuki, Y.; Miyashita, H.; Oike, Y.; Takahashi, T.; Nakamura, T.; Arioka, S.; Mitsuda, Y.; Takakura, T.; et al. Endogenous angiogenesis inhibitor vasohibin1 exhibits broad-spectrum antilymphangiogenic activity and suppresses lymph node metastasis. Am. J. Pathol. 2010, 176, 1950-1958. [CrossRef]

130. Hosaka, T.; Kimura, H.; Heishi, T.; Suzuki, Y.; Miyashita, H.; Ohta, H.; Sonoda, H.; Moriya, T.; Suzuki, S.; Kondo, T.; et al. Vasohibin-1 expression in endothelium of tumor blood vessels regulates angiogenesis. Am. J. Pathol. 2009, 175, 430-439. [CrossRef] [PubMed]

131. Kitahara, S.; Suzuki, Y.; Morishima, M.; Yoshii, A.; Kikuta, S.; Shimizu, K.; Morikawa, S.; Sato, Y.; Ezaki, T. Vasohibin-2 modulates tumor onset in the gastrointestinal tract by normalizing tumor angiogenesis. Mol. Cancer 2014, 13, 99. [CrossRef]

132. Koyanagi, T.; Suzuki, Y.; Saga, Y.; Machida, S.; Takei, Y.; Fujiwara, H.; Suzuki, M.; Sato, Y. In vivo delivery of sirna targeting vasohibin-2 decreases tumor angiogenesis and suppresses tumor growth in ovarian cancer. Cancer Sci. 2013, 104, 1705-1710. [CrossRef] 
133. Takahashi, Y.; Koyanagi, T.; Suzuki, Y.; Saga, Y.; Kanomata, N.; Moriya, T.; Suzuki, M.; Sato, Y. Vasohibin-2 expressed in human serous ovarian adenocarcinoma accelerates tumor growth by promoting angiogenesis. Mol. Cancer Res. 2012, 10, 1135-1146. [CrossRef]

134. Kobayashi, M.; Wakabayashi, I.; Suzuki, Y.; Fujiwara, K.; Nakayama, M.; Watabe, T.; Sato, Y. Tubulin carboxypeptidase activity of vasohibin-1 inhibits angiogenesis by interfering with endocytosis and trafficking of pro-angiogenic factor receptors. Angiogenesis 2020. [CrossRef] [PubMed]

135. Pagnamenta, A.T.; Heemeryck, P.; Martin, H.C.; Bosc, C.; Peris, L.; Uszynski, I.; Gory-Faure, S.; Couly, S.; Deshpande, C.; Siddiqui, A.; et al. Defective tubulin detyrosination causes structural brain abnormalities with cognitive deficiency in humans and mice. Hum. Mol. Genet. 2019, 28, 3391-3405. [CrossRef]

136. Gu, S.; Liu, Y.; Zhu, B.; Ding, K.; Yao, T.P.; Chen, F.; Zhan, L.; Xu, P.; Ehrlich, M.; Liang, T.; et al. Loss of alpha-tubulin acetylation is associated with tgf-beta-induced epithelial-mesenchymal transition. J. Biol. Chem. 2016, 291, 5396-5405. [CrossRef]

137. Bance, B.; Seetharaman, S.; Leduc, C.; Boeda, B.; Etienne-Manneville, S. Microtubule acetylation but not detyrosination promotes focal adhesion dynamics and astrocyte migration. J. Cell Sci. 2019, 132, jcs225805. [CrossRef] [PubMed]

138. Haggarty, S.J.; Koeller, K.M.; Wong, J.C.; Grozinger, C.M.; Schreiber, S.L. Domain-selective small-molecule inhibitor of histone deacetylase 6 (hdac6)-mediated tubulin deacetylation. Proc. Natl. Acad. Sci. USA 2003, 100, 4389-4394. [CrossRef] [PubMed]

139. Castro-Castro, A.; Janke, C.; Montagnac, G.; Paul-Gilloteaux, P.; Chavrier, P. Atat1/mec-17 acetyltransferase and hdac6 deacetylase control a balance of acetylation of alpha-tubulin and cortactin and regulate mt1-mmp trafficking and breast tumor cell invasion. Eur. J. Cell Biol. 2012, 91, 950-960. [CrossRef]

140. Montagnac, G.; Meas-Yedid, V.; Irondelle, M.; Castro-Castro, A.; Franco, M.; Shida, T.; Nachury, M.V.; Benmerah, A.; Olivo-Marin, J.C.; Chavrier, P. Alphatat1 catalyses microtubule acetylation at clathrin-coated pits. Nature 2013, 502, 567-570. [CrossRef]

141. Tran, A.D.; Marmo, T.P.; Salam, A.A.; Che, S.; Finkelstein, E.; Kabarriti, R.; Xenias, H.S.; Mazitschek, R.; Hubbert, C.; Kawaguchi, Y.; et al. Hdac6 deacetylation of tubulin modulates dynamics of cellular adhesions. J. Cell Sci. 2007, 120, 1469-1479. [CrossRef]

142. Rey, M.; Irondelle, M.; Waharte, F.; Lizarraga, F.; Chavrier, P. Hdac6 is required for invadopodia activity and invasion by breast tumor cells. Eur. J. Cell Biol. 2011, 90, 128-135. [CrossRef]

143. Whipple, R.A.; Vitolo, M.I.; Boggs, A.E.; Charpentier, M.S.; Thompson, K.; Martin, S.S. Parthenolide and costunolide reduce microtentacles and tumor cell attachment by selectively targeting detyrosinated tubulin independent from nf-kappab inhibition. Breast Cancer Res. 2013, 15, R83. [CrossRef]

144. Fonrose, X.; Ausseil, F.; Soleilhac, E.; Masson, V.; David, B.; Pouny, I.; Cintrat, J.C.; Rousseau, B.; Barette, C.; Massiot, G.; et al. Parthenolide inhibits tubulin carboxypeptidase activity. Cancer Res. 2007, 67, 3371-3378. [CrossRef]

145. Clemente-Ruiz, M.; Muzzopappa, M.; Milan, M. Tumor suppressor roles of cenp-e and nsl1 in drosophila epithelial tissues. Cell Cycle 2014, 13, 1450-1455. [CrossRef]

146. Silk, A.D.; Zasadil, L.M.; Holland, A.J.; Vitre, B.; Cleveland, D.W.; Weaver, B.A. Chromosome missegregation rate predicts whether aneuploidy will promote or suppress tumors. Proc. Natl. Acad. Sci. USA 2013, 110, E4134-E4141. [CrossRef] [PubMed]

147. Weaver, B.A.; Silk, A.D.; Montagna, C.; Verdier-Pinard, P.; Cleveland, D.W. Aneuploidy acts both oncogenically and as a tumor suppressor. Cancer Cell 2007, 11, 25-36. [CrossRef] [PubMed]

148. Zasadil, L.M.; Britigan, E.M.; Ryan, S.D.; Kaur, C.; Guckenberger, D.J.; Beebe, D.J.; Moser, A.R.; Weaver, B.A. High rates of chromosome missegregation suppress tumor progression but do not inhibit tumor initiation. Mol. Biol. Cell 2016, 27, 1981-1989. [CrossRef] [PubMed]

Publisher's Note: MDPI stays neutral with regard to jurisdictional claims in published maps and institutional affiliations. 